\title{
Intensifying transition states in newborns depending on the gender and mode of delivery - a prospective, comparative analysis
}

\author{
Nasilenie stanów przejściowych u noworodków w zależności od płci \\ i sposobu porodu - prospektywna analiza porównawcza
}

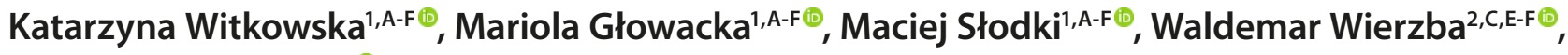 \\ Kinga Piórkowska',A-C๑ \\ ${ }^{1}$ Mazovian Public College, Poland \\ ${ }^{2}$ Warsaw Branch of the University of Humanities and Economics, Łódź, Poland \\ A - Research concept and design, B - Collection and/or assembly of data, C - Data analysis and interpretation, \\ $D$ - Writing the article, E-Critical revision of the article, F- Final approval of article
}

Witkowska K, Głowacka M, Słodki M, Wierzba W, Piórkowska K. Intensifying transition states in newborns depending on the gender and mode of delivery - a prospective, comparative analysis. Med Og Nauk Zdr. 2020; 26(2): 134-138. doi: 10.26444/monz/120128

\begin{abstract}
Introduction. Delivery is a physiological process stimulating the adaptation of the newborn to new conditions of life outside the mother's body The moment of the baby's birth and cutting the umbilical cord means the newborn's violent transition from the uterine environment to the external world, which requires the dynamic process of adaptation connected with numerous physiological states of transient character. The degree of the intensification of the transient states may still be different and cause deviations from the norm, or even transition into pathological states constituting the cause of a prolonged stay in hospital, invasive examinations and longterm treatment.

Objectives. The aim of the study was a comparative analysis of the intensification of the chosen transient states in the newborns born naturally, and those born through Caesarean section.
\end{abstract}

Materials and Method. In August-September 2018, 148 women and 148 newborns were qualified to the study. The exclusion criteria were mother's chronic diseases diagnosed before the pregnancy, delivery before the 37th week, negative blood group of the mother, and the newborn's Apgar result below 10 points.

Results. The newborns born naturally were more frequently fed only naturally ( $\mathrm{N}-55 ; 67.9 \%)$, in comparison to those born through caesarean section $(30 ; 44.7 \%)$. The body weight loss expressed in \% in relation to the birth body weight in the group SN reached $5.45 \%$, while in group CC $-6.26 \%(p=0.01275)$.

Conclusions. The newborns born naturally were more often fed naturally than those born through caesarean section. The physiological weight loss in the first days was greater in newborns born via caesarean section than those born naturally.

\section{Key words}

transition states, vaginal birth, caesarian section, birth Wright

\section{Streszczenie}

Cel pracy. Poród jest procesem fizjologicznym stymulującym dostosowanie noworodka do nowych warunków życia poza ciałem matki. Moment porodu dziecka i przecięcie pępowiny oznacza gwałtowne przejście noworodka ze środowiska macicy do zewnętrznego, co wymaga dynamicznego procesu adaptacji związanej z licznymi stanami fizjologicznymi o charakterze przejściowym. Celem pracy była analiza porównawcza nasilenia wybranych stanów przejściowych u noworodków urodzonych naturalnie i przez cesarskie cięcie.

Materiał i metody. Do badania przeprowadzonego w sierpniu i wrześniu 2018 roku zakwalifikowano 148 kobiet i 148 noworodków. Elementami wykluczającymi były przewlekłe choroby matki zdiagnozowane przed ciążą, poród przed 37 tygodniem, ujemna grupa krwi matki, wynik Apgar noworodka poniżej 10 punktów.

Wyniki. Noworodki urodzone naturalnie były częściej karmione wyłącznie naturalnie ( $\mathrm{N}=55 ; 67,9 \%)$ w porównaniu do tych urodzonych przez cesarskie cięcie (30; 44,7\%). Utrata masy ciała wyrażona w procentach w stosunku do urodzeniowej masy ciała w grupie SN osiągnęła 5,45\%, zaś w grupie CC $6,26 \%(p=0,01275)$.

Wnioski. Poród siłami natury sprzyja karmieniu naturalnemu. Fizjologiczna utrata masy ciała w pierwszych dniach była większa u noworodków urodzonych przez cesarskie cięcie niż u urodzonych siłami natury.

\section{Słowa kluczowe}

masa urodzeniowa, cesarskie cięcie, stany przejściowe 


\section{INTRODUCTION}

Delivery is a physiological process stimulating the adaptation of the newborn to new conditions of life outside the mother's body [1]. It may proceed in a natural mode or through caesarian section, constituting the most frequent treatment procedure conducted in women worldwide. According to the WHO, caesarean section should terminate $5-15 \%$ of deliveries. According to Polish and world statistics, the percentage of caesarean sections considerably exceeds the above assumptions, and in 2006 in the USA reached 31.1\% [2], while in Poland in $2015-43 \%$ [3].

The moment of the baby's birth and cutting the umbilical cord means the newborn's violent transition from the uterine environment to the external world, which requires the dynamic process of adaptation connected with numerous physiological states of transient character. The degree of the intensification of the transient states may still be different and cause deviations from the norm, or even transition into pathological states constituting the cause of a prolonged stay in hospital, invasive examinations and long-term treatment. Hence, observation and evaluation of the transition states at every stage is necessary [4]. The leading role in this field is played by the midwife taking care of the mother and the child. Conducting continuous observation she differentiates physiological states from the pathological, and conducts adequate education oriented at the parents $[5,6]$. The most frequent transient states in the newborn include: physiological jaundice, physiological body loss, transient stools, pregnancy reactions, newborn erythema, and physiological increase in body temperature [7]. In the available literature, there is no comparative research of the transient states in the newborns born naturally and those born through caesarean section

\section{OBJECTIVE}

The aim of the study was a comparative analysis of the intensification of the chosen transient states in newborns born naturally, and those born through caesarean section.

\section{MATERIALS AND METHOD}

Inducted in August - September 2018, 148 women and 148 newborns were qualified to the study. The exclusion criteria were the mother's chronic diseases diagnosed before the pregnancy, delivery before the 37 th week, negative blood group of the mother, and the newborn's Apgar result below 10 points. Participation in the study was voluntary. The patients were informed about the essentials and purpose of the study and agreed to participate in that in writing.

There were 2 groups identified, depending on the mode of the baby's delivery. Group VB - vaginal birth, babies born naturally (N-81;100\%) and group CS - caesarean section, newborns from caesarean sections (N-67; 100\%). Physiological jaundice was measured on the 3rd day of life with a bilirubin meter which measures the bilirubin in $\mathrm{mg} / \mathrm{dl}$ through the skin. The measurements were taken on the forehead and the chest. Physiological loss of the body mass was identified in \% out of the daily measurements of the newborn's body weight. For the sake of standardization, the body mass loss was expressed in grams, after which the percentage of the loss vs. the birth weight was calculated. The analysis included the highest percentage of body mass loss in the first days. Data regarding the first stool, pregnancy reactions, and newborn erythemas were collected from observation and assessment of each of the baby's measurements.. Body temperature was measured on the 3rd day through the skin on the belly - the result was expressed in ${ }^{\circ} \mathrm{C}$.

The results were subjected to statistical analysis using the t-Student, U Mann-Whitney,-Chi-quarter Pearson tests, and the Chi-square test with Yates improvement.

\section{RESULTS}

The demographic features of the study groups did not differ significantly statistically. The average age of the mothers was 30 , via caesarian section $-30.04(+/-4.90)$ and by natural delivery - 29.32 (+/-5.34) (Tab. 1). In both groups, predominated women who gave birth naturally. The women examined had academic education and lived in a city or in town (Tab. 1).

Intensification of physiological jaundice measured with a bilirubin meter (mg/dl) was not significantly statistically divergent from the mode of delivery $\left(\mathrm{p}=0.08164^{2}\right)$. The average level of bilirubin in group VB reached $8.4(5.7-10.3) \mathrm{mg} / \mathrm{dl}$, while in group CS - 7.1 (5.7-8.9) mg/dl. (Tab. 2).

There were no statistically significant differences between the incidence of the newborn erythema depending on the mode of delivery. In group VB, erythema intensified in 12 newborns (14.8\%), and in the group CS, - 11 newborns (16.4\%). In the remaining babies in the adaptation period there were no analyzed skin changes. (Tab. 2).

The next transition state compared between the group of newborns delivered naturally and through caesarean section was the physiological increase in body temperature on the 3rd day of life. The average body temperature of the newborns amounted to $36.9^{\circ} \mathrm{C}$ and maintained between $36.8-37.0^{\circ} \mathrm{C}$ in both groups (Tab. 2).

Most babies had the first stool in the $1^{\text {st }}$ hour (group VB: $\mathrm{N}-26 ; 32.0 \%$, and in group CS: $\mathrm{N}-15 ; 22.3 \%)$, at the $12^{\text {th }}$ hour (group VB: N- 25; $30.8 \%$ and group CS: N- 39; $58.2 \%$ ) and the $2^{\text {nd }}$ hour of life (group VB: N- 20; $24.6 \%$ and group CS: N- 10; 14.9\%), $\left(\mathrm{p}=0,1224^{2}\right)$ (Tab. 2).

Pregnancy reactions in the form of swollen mammary glands in the newborns were not often discovered during the transition states, and concerned 3 children in group VB (3.7\%) and 8 (11.9\%) in the group CS, respectively (Tab. 2).

Table 1. Demographic characteristics of the groups examined

\begin{tabular}{|c|c|c|c|c|c|c|}
\hline \multirow{2}{*}{\multicolumn{2}{|c|}{ Category }} & \multicolumn{2}{|c|}{ Vaginal birth } & \multicolumn{2}{|c|}{ Cesarean section } & \multirow{2}{*}{$\mathrm{p}$} \\
\hline & & $\mathrm{n}$ & $\%$ & $\mathrm{n}$ & $\%$ & \\
\hline \multicolumn{2}{|l|}{ Age } & $29.32(+/-5.34)$ & - & $30.04(+/-4.90)$ & - & $p=0.3958^{1}$ \\
\hline \multicolumn{2}{|c|}{ Number of deliveries } & $2(1-2)$ & - & $2(1-2)$ & - & $p=0.4230^{2}$ \\
\hline \multirow[t]{2}{*}{ Address } & city & 46 & 56.7 & 43 & 64.1 & $p=0.3608^{3}$ \\
\hline & village & 35 & 43.2 & 24 & 35.8 & \\
\hline \multirow[t]{5}{*}{ Education } & primary & 4 & 4.9 & 2 & 2.9 & $p=0.9095^{4}$ \\
\hline & middle & 5 & 6.1 & 3 & 4.4 & \\
\hline & secondary & 28 & 34.5 & 26 & 38.8 & \\
\hline & vocational & 6 & 7.4 & 5 & 7.4 & \\
\hline & higher & 38 & 46.9 & 31 & 46.2 & \\
\hline \multirow[t]{2}{*}{$\begin{array}{l}\text { Newborn's } \\
\text { sex }\end{array}$} & male & 42 & 51.8 & 32 & 47.7 & $p=0.6203^{3}$ \\
\hline & female & 39 & 48.1 & 35 & 52.2 & \\
\hline
\end{tabular}


Table 2. Transition states in newborns depending on the mode of delivery

\begin{tabular}{|c|c|c|c|c|c|c|}
\hline \multirow{2}{*}{ Transition state } & & \multicolumn{2}{|c|}{ Vaginal birth } & \multicolumn{2}{|c|}{ Cesarean section } & \multirow[t]{2}{*}{$\mathrm{p}$} \\
\hline & & $\mathrm{n}$ & $\%$ & $\mathrm{n}$ & $\%$ & \\
\hline Physiological jaundice & & $8,4 \mathrm{mg} / \mathrm{dl}$ & - & $7,1 \mathrm{mg} / \mathrm{dl}$ & - & $p=0.03273^{2}$ \\
\hline \multirow{2}{*}{ Newborn erythema } & intensified & 12 & 14.8 & 11 & 16.4 & $\mathrm{p}=0.7887^{3}$ \\
\hline & none & 69 & 85.1 & 56 & 83.5 & \\
\hline \multicolumn{2}{|l|}{ Body temperature on the 3 rd day } & $36.9(36.8-37.0)$ & & $36.9(36.8-37.0)$ & & $\mathrm{p}=0.2272^{2}$ \\
\hline & after $1 \mathrm{~h}$ & 1 & 1.2 & 0 & 0 & \\
\hline & after $2 \mathrm{~h}$ & 20 & 24.6 & 10 & 14,9 & \\
\hline & after $12 \mathrm{~h}$ & 25 & 30.8 & 39 & 58.2 & \\
\hline & after $24 \mathrm{~h}$ & 9 & 11.1 & 3 & 4.4 & \\
\hline Pregnancy reactions & Swollen mammary glands & 3 & 3.7 & 8 & 11.9 & $p=0.1176^{4}$ \\
\hline Maximum body weight loss $\%$ in relation to birth weight & & - & $5.45(+/-2.00)$ & - & $6.26(+/-1.90)$ & $p=0.01275^{1}$ \\
\hline \multicolumn{7}{|l|}{ Method of feeding } \\
\hline Natural & & 55 & 67.9 & 30 & 44.7 & $p=0.03992^{4}$ \\
\hline Mixed & & 24 & 29.6 & 35 & 52.2 & \\
\hline Artificial & & 2 & 2.4 & 2 & 2.98 & \\
\hline
\end{tabular}

The newborns born naturally were more frequently fed only naturally (N-55;67.9\%), compared to those born through caesarean section (30;44,7\%). Mixed feeding of the children in group VB was chosen by 24 mothers (29.6\%), while in group CS - 35 women (52.2\%). In both groups, 2 mothers decided to feed the newborns only with an artificial mixture (Fig. 1, Tab. 2).

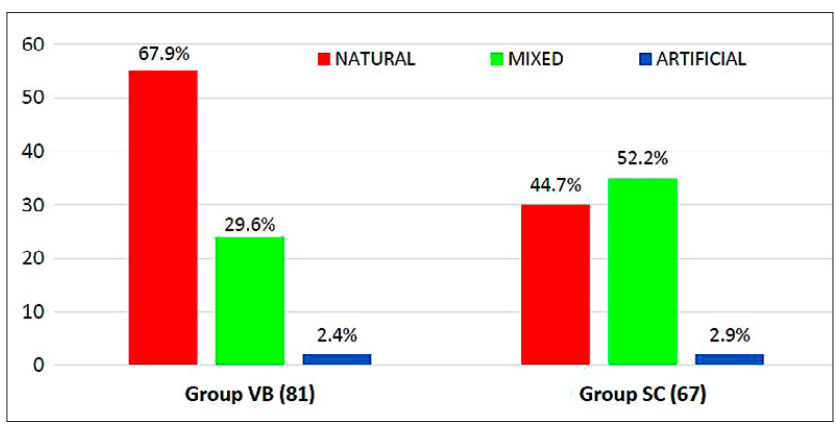

Figure 1. Baby feeding depending on the mode of delivery

Body weight loss expressed in \% in relation to the birth body weight in the group VB reached $5.45 \%$, while in group CS - 6.26\%. ( $p=0.01275$ ) (Fig. 2, Tab. 3).

The correlation for the continuous variables (Tab. 3) demonstrated significant statistically dependence between the level of bilirubin and the post-delivery loss of body mass (Fig. 3).

Table 3. Correlation for continuous variables

\begin{tabular}{lcc}
\hline Correlations & Correlation coefficient & $\mathrm{P}$ - value \\
\hline Age vs. jaundice & $\mathrm{r}=-0.07082$ & $\mathrm{p}=0.3924^{1}$ \\
\hline Age vs. temperature & $\mathrm{r}=-0.03966$ & $\mathrm{p}=0.6323^{1}$ \\
\hline Age vs. \% body weight loss & $\mathrm{r}=0.04270$ & $\mathrm{p}=0.6064^{2}$ \\
\hline Jaundice vs. temperature & $\mathrm{r}=-0.03273$ & $\mathrm{p}=0.6930^{1}$ \\
\hline Jaundice vs. \% body weight loss & $\mathbf{r}=\mathbf{0 . 1 6 7 1}$ & $\mathbf{p}=\mathbf{0 . 0 4 2 3 4 ^ { 1 }}$ \\
\hline Temperature vs. \% body weight loss & $\mathrm{r}=-0.01833$ & $\mathrm{p}=0.8250^{2}$ \\
\hline
\end{tabular}

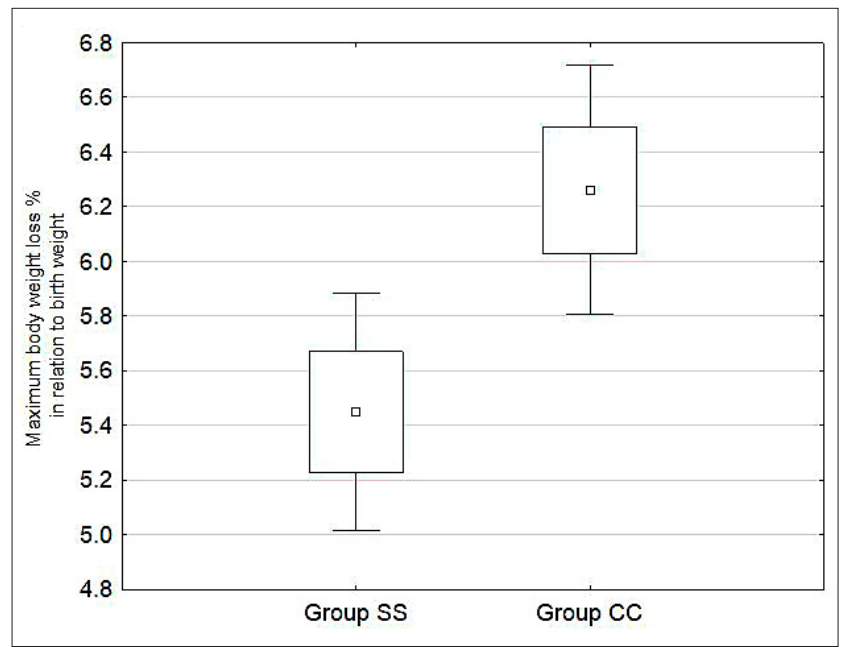

Figure 2. Difference in body weight loss depending on the mode of delivery

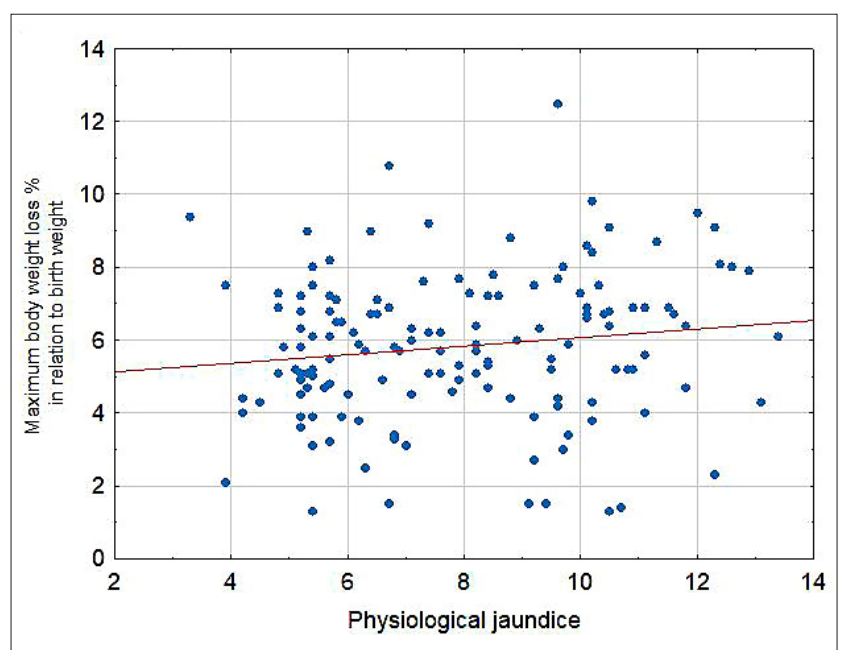

Figure 3. Correlation of physiological jaundice and the maximum body loss of the newborn (\%) 
In analyzing the transition states in newborns depending on their gender there were significant divergences in the result obtained. In the case of physiological jaundice in the male newborns, there was a higher level o bilirubin - $8.65(6.5-10.2)$ $\mathrm{mg} / \mathrm{dl}$, compared to that of the females - 6.55 (5.40-9.20) $\mathrm{mg} / \mathrm{dl}$ (Tab. 5). Newborn erythema was diagnosed in 17 girls (22.9\%) and 6 boys (8.1\%) (Tab. 4$)$

Table 4. Intensification of transition states depending on the newborn's sex

\begin{tabular}{|c|c|c|c|c|c|c|}
\hline \multirow{2}{*}{\multicolumn{2}{|c|}{ Transition state }} & \multicolumn{2}{|c|}{ Male sex } & \multicolumn{2}{|c|}{ Female sex } & \multirow{2}{*}{$\mathrm{p}$} \\
\hline & & $\mathrm{n}$ & $\%$ & $\mathrm{n}$ & $\%$ & \\
\hline \multirow[t]{2}{*}{$\begin{array}{l}\text { Newborn } \\
\text { erythema }\end{array}$} & Intensified & 6 & 8.1 & 17 & 22.9 & $p=0.02328^{4}$ \\
\hline & none & 68 & 91.8 & 57 & 77.0 & \\
\hline \multirow[t]{5}{*}{ stool } & in $1 \mathrm{st} h$ & 18 & 24.3 & 23 & 31.0 & $\mathrm{p}=0.2829^{3}$ \\
\hline & after 1st h & 1 & 1.3 & 0 & 0 & \\
\hline & after $2 \mathrm{~h}$ & 12 & 16.2 & 18 & 24.3 & \\
\hline & after $12 \mathrm{~h}$ & 38 & 51.3 & 26 & 35.1 & \\
\hline & after $24 \mathrm{~h}$ & 5 & 6.7 & 7 & 9.4 & \\
\hline \multirow[t]{2}{*}{$\begin{array}{l}\text { Pregnancy } \\
\text { reaction }\end{array}$} & $\begin{array}{l}\text { Swollen } \\
\text { mam mary } \\
\text { glands }\end{array}$ & 6 & 8.1 & 5 & 6,7 & $p=0.9813^{4}$ \\
\hline & none & 68 & 91.8 & 69 & 93.2 & \\
\hline \multicolumn{2}{|c|}{$\begin{array}{l}\text { Temperature on the } \\
\text { 3rd day }\end{array}$} & $\begin{array}{c}36.9 \\
(36.8-37.0)\end{array}$ & - & $\begin{array}{c}36.9 \\
(36.8-37.0)\end{array}$ & - & $\mathrm{p}=0.5892^{2}$ \\
\hline \multicolumn{2}{|c|}{ Physiological jaundice } & $\begin{array}{c}8.65 \\
(6.5-10.2) \\
\end{array}$ & - & $\begin{array}{c}6.55 \\
(5.40-9.20) \\
\end{array}$ & - & $\mathrm{p}=0.03273^{2}$ \\
\hline \multicolumn{2}{|c|}{$\begin{array}{l}\text { Maximum body weight } \\
\text { loss } \% \text { in relation to } \\
\text { birth weight }\end{array}$} & $\begin{array}{c}5.63 \\
(+/-2.02)\end{array}$ & - & $\begin{array}{c}6.00 \\
(+/-1.96)\end{array}$ & - & $\mathrm{p}=0.2691^{1}$ \\
\hline
\end{tabular}

\section{DISCUSSION}

The mode of delivery is continuously analyzed with respect to its impact on the health of both the mother and the baby $[8,9,10,11]$. The current study attention was paid to the first hours and days of life of the newborns, comparing the most frequent transition states depending on the mode of delivery. The results concerning the physiological body weight loss in the newborns can be juxtaposed against studies carried out in Spain (2018) by López et al. Both proved that caesarean section was a factor determining a bigger loss of body weight in the newborns in the first days of life in relation to the birth weight [12]. The results from feeding the baby depending on the mode of delivery confirmed the findings of Józefów et al. in which natural delivery favoured the length of exclusive natural feeding, delivering the baby through caesarean section lessened the chances for full natural feeding [13]. Other authors also supported the negative influence of caesarean section on the natural feeding of the newborn [14, 15]. In theoretical reports, there were no essential statistical differences proven in the intensification of jaundice in the newborns in the first days after being born naturally and through caesarean section [10].

The observed and compared frequent aberrations in the post-delivery period and the benefits from the particular modes of delivery are not always obvious. There has been no evidence of significant statistical data in the post-delivery period of the physiological and caesarean section delivery, although other problems were identified, e.g. those of a psychic nature which may contribute to the ever-growing number of caesarean sections [8].

The fact that the mode of delivery is not without meaning its condition and the adaptation period were proved by research published conducted in the USA within the Project NIH (National Institute of Health) in 2008, concerning 2 million deliveries of newborns in $39 \mathrm{hbd}$ resulting from correctly proceeding pregnancies - 1 million caesarean sections and 1 million natural deliveries. The study showed an increase in the number of deaths of newborns, and significantly increased frequency of breathing disorders in the newborns from caesarean sections [9]. Mikulska and Simon proved that treating caesarean sections as risk factor for the incidence of delivery changes in the central nervous system with first time delivery, and as the indication for ultrasonography in the newborn. These results have inspired the continuation of studies in the respect [10].

During natural delivery, the newborns come into contact with the bacterial flora of the mother's vagina and anus. The sterile environment the newborn in the caesarian section therefore disturbs the proper colonization of its digestive system. In assessing the microbiological profile of the faeces of the babies born naturally and the caesarean section, it has been reported that in the latter case the colonization by the Bacteroides sp. did not appear before the $2^{\text {nd }}$ month of life, while the degree of colonization by those bacteria in the $6^{\text {th }}$ month of life constituted half of that reported in babies born naturally. Besides, in the newborns delivered naturally, the colonization by the bacteria Lactobacillus i Bifidobacter was higher than in the group born through caesarean section. The deregulation (dysbiosis) of that process in the early post-delivery period may constitute the basis for the further inflammatory, resistant and allergic disorders. Similar conclusions were drawn in 2 other studies describing the factors influencing the colonization of the digestive system, and later consequences connected with it $[16,17]$.

There were transient states and their intensification analysed depending on the gender of the newborn. The results showed that gender may be a factor influencing the level of bilirubin in the first days after delivery. Male newborns had a higher level of bilirubin, compared to female newborns. Analysis showed that the female gender may be essential for the frequency of newborn erythema (Tab. 4). In the literature there are studies on gender which suggest that the female foetus has an advantage over the male foetus concerning general development in the post-delivery period. Male gender may be an independent factor for an unfavourable pregnancy [18]. Gender influences not only mother's mode of delivery, but also the way the newborn confronts the external world. The study shows that the gender of the newborn is a decisive factor connected with some functional changes which are influential for both mother and baby after delivery [19]. The presented research and conclusions concerning the dependence on the mode of delivery and the gender of the baby require the continuation in a more numerous groups of newborns.

\section{CONCLUSIONS}

1. The newborns born naturally were more often fed naturally than those born through caesarean section. 
2. The physiological weight loss in the first days was greater in newborns born via caesarean section than those born by naturally.

3. Analysis of physiological jaundice measured with a bilirubin meter and its contingency on the mode of delivery did not demonstrate significant statistical differences, but the gender of the baby may be a factor in the intensification of physiological jaundice.

4. The appearance of pregnancy reactions, newborn erythe$\mathrm{ma}$, and the first stool, is not dependent on the fact whether the delivery proceeded naturally or through caesarean section.

\section{REFERENCES}

1. Michałowska S, Zalewski M, Heimrath J, Zalewski J. Analiza sposobów ukończenia ciąży na podstawie preferencji ciężarnych oraz danych statystycznych z lat 2006-2010. Nowa Medycyna 2012; 4: 67-75.

2. Rubin R. Answers prove elusive as $\mathrm{C}$-section rate rises. USA Today 2012; $7: 1$.

3.Zarząd Główny Polskiego Towarzystwa Ginekologicznego: Cięcie cesarskie: rekomendacje Polskiego Towarzystwa Ginekologicznego

4. Kordek A. Stany przejściowe u noworodka - co to takiego? Pediatr Dypl. 2016; 20(1): 51-60.

5. Standard Opieki Okołoporodowej z dnia 20 września 2012 (Dz.U Poz. 1100).

6. Sahaj D, Pałczyńska M, Hańczyc P, Żelazko K. Wiedza matek na temat stanów przejściowych noworodka. Badania naukowe w pielęgniarstwie i położnictwie. 2015; 2: 421-432.
7. Świetliński J. Neonatologia i opieka nad noworodkiem. Wydawnictwo Lekarskie PZWL. 2016; 1: 110-117.

8. Pomorski, Woytoń R, Woytoń P, Kozłowska J, Zimmer M. Cięcia cesarskie a porody siłami natury - aktualne spojrzenie. Ginekol Pol. 2010; 81: 347-351.

9. Signore C, Klebanoff M. Neonatal morbidity and mortality after elective cesarean delivery. Clin Perinatol. 2008; 35: 361-371.

10. Mikulska M, Simon M. Cięcie cesarskie jako czynnik ryzyka wystąpienia okołoporodowych zmian OUN u noworodka. Perinatol Neonatol Ginekol. 2008; 1: 213-216.

11. Sharma R, Young C, Mshvildadze M, Neu J. Intestinal Microbiota: Does it play a role in diseases of the neonate? Neo Reviews Org. 2009; 10: $166-179$.

12. López G, Cadenasso G, Cadenasso G. Weight decrease in full-term newborns in the first 48 hours postnatal. Rev Chil Pediatr. 2018; 89: 325-331.

13. Józefów P, Przestrzelska M, Knihinicka-Mercik Z. Przebieg laktacji we wczesnym połogu u kobiet po porodzie siłami natury i przez cesarskie cięcie z uwzględnieniem rodności kobiety. Piel Zdr Publ. 2013; 3: $133-142$.

14. Tully KP, Ball HL. Maternal accounts of their breast-feeding intent and early challenges after caesarean childbirth. Midwifery. 2014; 30(6): 712-719.

15. Isik Y, Dag ZO, Tulmac OB, Pek E. Early postpartum lactation effects of cesarean and vaginal birth. Ginekol Pol. 2016; 87(6): 426-30.

16. Witkowska-Wirstlein R, Jurczyk M. Czynniki determinujące kolonizację przewodu pokarmowego noworodków. Polski Przegląd Nauk o Zdrowiu 2016; 3(48): 285-289.

17. Penders J, Thijs C, Vink C, Stelma FF, Snijders B, Kummeling I, van den Brandt PA, Stobberingh EE. Factors influencing the composition of the intestinal microbiota in early infancy. Pediatrics. 2006; 118(2): 511-521.

18. Di Renzo GC, Rosati A, Sarti RD, Cruciani L, Cutuli AM. Does fetal sex affect pregnancy outcome? Gend Med. 2007; 4(1): 19-30.

19. Johan G, Kajantie E, Osmond C, Thornburg K, Barker D. Boys Live Dangerously in the Womb, Am J Hum Biol. 2010; 22(3): 330-335. 